\title{
Work Ethic in China Changes over Time from 2004 to 2018
}

\author{
Zhaojie Cao $^{1,}$, , Roger B. Hill ${ }^{2}$ \\ ${ }^{1}$ Institute of Higher Education Research, Sichuan University of Sciences \& Engineering, Zigong, P. R. C. \\ ${ }^{2}$ Department of Career \& Information Studies, College of Education, The University of Georgia, Athens, Georgia
}

Email address:

zjcao@suse.edu.cn (Zhaojie Cao)

*Corresponding author

\section{To cite this article:}

Zhaojie Cao, Roger B. Hill. Work Ethic in China Changes over Time from 2004 to 2018. International Journal of Vocational Education and Training Research. Vol. 5, No. 1, 2019, pp. 10-15. doi: 10.11648/j.ijvetr.20190501.12

Received: January 3, 2019; Accepted: February 14, 2019; Published: March 26, 2019

\begin{abstract}
Work ethic was a persistent concern in the work place during the 20th century and continues to be important in the 21 st century as well. Key components of work ethic include interpersonal skills, initiative, and dependability. This study examined significant changes on the work ethic differences between women and men in two samples of work ethic data collected over a fourteen year period of time. One data set was gathered from 201 working adults in China in 2004 and the other was collected from 248 working adults in 2018. Data was gathered using a Chinese translation of the Occupational Work Ethic Inventory (OWEI) constructed by Petty (1993). Significant differences were measured for initiative between women and men in the 2004 data set, but not in the 2018 data set. No significant differences were detected between women and men for interpersonal skills or dependability in either set of data. A review of literature and discussion is provided to explain changes over time in initiative of Chinese women and men. The findings reveal some interesting insights into the Chinese workforce during a time when the economy has been rapidly developing.
\end{abstract}

Keywords: Work Ethic, China, Gender Differences, Occupational Work Ethic Inventory

\section{Introduction}

Work ethic is one of the most critical worker qualifications for the workplace of the $21^{\text {st }}$ century and it has received considerable attention from employers in recent years (Bengt, Hakansson \& Jan 2012; Jesook, 2011; Jill \& Linda 2006). [13] Jill found that a combination of basic knowledge and applied skills are perceived to be critical for new entrants' success in the 21 st century U.S. workforce, and the top five "most important" work traits for employees are applied skills. These important applied skills consisted of professionalism and work ethic, teamwork, and collaboration and oral communications. If employees lack work ethic and related attributes, productivity is impacted and economic vitality is impaired.

\section{Literature Review}

The importance of work ethic for success on the job is not a new phenomenon. Weber (1905) [4] identified the significant of the Protestant ethic, a form of work ethic, from an economic perspective over a century ago. Others have identified the importance of work ethic and its relevance to well-being on the job. For example, an employee's work ethic can affect one's self-esteem (Xu S, Wang Q, 2013) [5]. A low self-esteem can cause low job satisfaction and diminished motivation resulting in poor work performance (Cynthia Le Rouge, Anthony Nelson, J. Ellis Blanton, 2006). [6] Previous studies have demonstrated a positive link between a strong work ethic and worker productivity. Merrens and Garrett (1975) found that workers with a strong Protestant ethic spent more time working and produced more output. [7] Their research revealed a relatively large effect size for the impact of work ethic on time spent on task $(\mathrm{d}=$ $1.10)$ and work completed $(d=1.58)$. Similarly, Greenberg (1977) found a moderate effect of work ethic on task persistence $(\omega 2=0.47)$. [8] Blood (1969) reported a mean correlation of 0.17 between work ethic and job satisfaction. [9] The evidence is clear that insights and increased understanding of this social norm are relevant to improved efficiency and competitiveness in the workplace.

In the competitive job market of the $21^{\text {st }}$ century, 
employers are looking for employees who not only have technical competence, but also exhibit strong work ethic traits. Employers recognize that work ethic provides a competitive edge in a globally competitive market because it increases productivity (Marion Hersh, 2017; Berry \& Glen, 2004). [10-11] Employees with a solid work ethic are driven in their mind and hearts with a desire to achieve personal excellence, satisfaction, and success through hard work while being willing to put forth effort at all times (Yahya Safari, Nasrin Yoosefpour, 2017; Gitmore, 2007). [12-13]

Previous work ethic research has revealed that work ethic can vary among individuals. Some of these studies identified work ethic differences based on demographic characteristics, especially existing among men and women (Hamid \& Mahdi, 2011, P133; John, Taylor \& David, 2009, P209; D'Arcy \& Ingrid 2007, P77; Elizur, 1994, P201; Petty \& Hill, 1994, P71; Wayne 1989, P793; Furnham \& Muhiudeen, 1984, P157; Miller, 1981, P1; David J. Cherington, 1980, P45). [14-22] Cherington reported that women scored higher than men with regard to pride in doing a job well and on being hard workers. Hill and Petty (1995) reported that women scored higher than men for dependability, interpersonal skills, and initiative, all of the work ethic attributes measured by the subscales of the Occupational Work Ethic Inventory (OWEI). [23] Awareness of any patterns of work ethic differences within the workforce can provide a competitive edge to employers seeking to place workers in optimal positions and achieve maximum efficiencies.

Members of the business community continue to express concerns about the work ethic - a commitment to the value and importance of hard work - among potential employees, and some believe that work ethic is declining both in America as well as other industrialized countries (Eisenberger, 1989; Michael, 2002; John 2009; Hamid \& Mahdi, 2011). [24-25] Concern has been expressed that the decline in work ethic corresponds to lower levels of job performance (John T. Parkhurst, Matthew S. Fleisher, etc., 2011), [26] higher levels of absenteeism and turnover and increases in counterproductive behavior ranging from unauthorized breaks to employee theft (Liu Jing, 2011) [27]. Others have argued that work ethic is not in decline; rather, the work ethic among those classified as "Generation X" is different than that of previous generations (D'Arcy A. Becker \& Ingrid Ulstad, 2007; Mary Stergiou-Kita, Marc Lafrance, Cheryl Pritlove, 2017) [28-29]. In 2009, Harvell completed a study patterned on some of the initial work of Hill (1995) [32] and found that some of the demographic differences detected in the 1990's workplace were no longer prominent in $21^{\text {st }}$ century workers. In particular, she found that differences between men and women were no longer statistically significant across the factors measured by the OWEI. In her study, data from respondents grouped by gender did not show any statistically significant difference for the subscales of dependability and initiative. She did, however, detect a significant difference between men and women for interpersonal skills with women scoring higher than men. Having current knowledge about differences in work ethic based on demographics and other trends within the workforce is not only of interest to employers, but also can provide a competitive advantage.

In the global economy of the $21^{\text {st }}$ century, it is not sufficient to only have familiarity with characteristics of the workforce in the US. A major portion of the work driving the global economy is done in other places. For example, the US now depends on workers in China for assembly of products such as the iPhone, iPad, Android mobile phones and other popular electronic products, and US markets are filled with textiles, clothing, furniture, and other goods from China. The US- China trade figures for 2011 illustrate the continuing increase in Chinese production that has become even more pronounced since 2000. According to a new Manufacturers Alliance for Productivity and Innovation (MAPI) report (Steve, 2012) [30], in the final three quarters of 2012, bilateral trade between U.S. and China amounted to 355.42 billion US dollars and this made China the largest exporter of products for the western world (LV, 2012). [31] One of the most prominent concerns related to this shift is the quality of these products and that is directly influenced by the characteristics of Chinese workers. Just as in other parts of the world, work ethic is an essential ingredient and it is important to understand the work ethic of Chinese workers. Little research has been conducted, however, to examine work ethic in the context of the Chinese workplace and much is needed.

In considering the work ethic of Chinese workers, it is apparent that the cultural heritage and the social influences that shape the Chinese work ethic differ from those in the US where much of the previous work ethic research has been conducted. While that research is based on characteristics that contribute to success in the US workplace, most if not all happen in the different situation.

For purposes of this study, work ethic is defined as a value associated with people who work hard, are productive, and who are usually successful due to their efforts (Berry \& Glen, 2004). According to previous research on the Protestant work ethic, some traits associated with a strong work ethic include asceticism, integrity, independence, diligence, motivation, loyalty, and dependability (Hill, 1996; Petty, G. C., \& Hill, R. B, 2005). [32-33] Functionally, the subscales of the OWEI describe the themes or categories of behaviors to be considered in this study. While other labels for elements of work ethic exist in the literature, this study continues a line of work that was begun by Hill and Petty over 20 years ago and uses descriptors that can be easily addressed by those responsible for both worker selection and employee training.

\section{Purpose of the Study}

The purpose of this study was to investigate work ethic changes over a period of fourteen years by using a data from working adults in Chinese workplaces. The data were gathered in 2004 and 2018 with questionnaire of OWEI of Chinese version in China. The study addressed these research questions: 
(1) Is there a statistically significant difference in work ethic scores for dependability between men and women for workers in 2004 and in 2018 ?

(2) Is there a statistically significant difference in work ethic scores for interpersonal skills between men and women for workers in 2004 and in 2018 ?

(3) Is there a statistically significant difference in work ethic scores for initiative between men and women for workers in 2004 and in 2018 ?

\section{Method}

The survey instrument used in this study was the Occupational Work Ethic Inventory (OWEI) developed by Petty in 1991. The OWEI is an established instrument for work ethic research. It has been used in previous studies by Hatcher (1995), Hill (1992), Petty and Hill (1994). The OWEI is comprised of 50 items. The stem of the instrument is "As a worker I can describe myself as:" for 50 descriptors of work behaviors that align with work ethic attributes. Each instrument item is assigned a value by the person completing it using a seven point Likert scale with the following labels: 1 $=$ Never, $2=$ Almost Never, $3=$ Seldom, $4=$ Sometimes, $5=$ Usually, $6=$ Almost Always, and $7=$ Always. The simplicity of the instrument design and the universal nature of descriptors of a positive work ethic lend themselves to a valid and reliable instrument in multiple languages. The OWEI has been translated into Spanish, French, German, Arabic, Korean, Chinese, and Greek. The original translation of the OWEI into Chinese was done by an academic who was fluent in both English and Chinese. Reverse translations was then completed by Chinese tour guides who had excellent English language skills. Two iterations of reverse translation were needed to refine the original work.

We examined gender differences of work ethic of OWEI with 284 men and 165women respondents. Data gathered from Chinese factories in the year of 2018 and 2004. There were 248 effective questionnaires in 2018 and 201 in 2004 was used for our study. The demographic composition of each year was comparable, where males were $59.27 \%$ and $40.73 \%$ females in 2018, and $68.16 \%$ males and $31.84 \%$ females in 2004. All respondents were quite similar in terms of demographic characteristics and they had the same work experience in workshops.

In order to determine if work ethic differences varied by gender among each items in the year of 2004 and 2018, we implemented a comparative analysis. Comparison analysis involves reviewing the data that have been collected and comparing each item with others that have been collected, looking for similarities between the two year's data. Through this process, categories were formed with data that share similar themes. Data were independently coded and themes identified by Hill with interpersonal skills, initiative and dependable (Petty \& Hill, 2005). [33].

\section{Results}

Table 1 shows the frequency and percentage distribution of respondents' gender for each year. Means and standard deviations for interpersonal skills, initiative and dependable are presented in Table 2. As can be seen in the table, means on these items in 2018 were decreased both for male and female by comparing with them in 2004. The greatest deduction on dependable suggests that women employees changed their perception of work ethic and they did not have strong sense of dependable than before. Furthermore, the means of each item for Male in 2018 was a little bit higher than female. The higher grates of the means show that male employees have stronger work ethic perceptions on each items than female.

Table 1. Frequency Distribution of Sex for Each Year.

\begin{tabular}{|c|c|c|c|c|c|c|c|c|}
\hline Year & 2018 & & & & 2004 & & & \\
\hline Sex & Frequency & Percentage & $\begin{array}{l}\text { Cumulative } \\
\text { Frequency }\end{array}$ & $\begin{array}{l}\text { Cumulative } \\
\text { Percentage }\end{array}$ & Frequency & Percentage & $\begin{array}{l}\text { Cumulative } \\
\text { Frequency }\end{array}$ & $\begin{array}{l}\text { Cumulative } \\
\text { Percentage }\end{array}$ \\
\hline Men & 147 & 59.27 & 147 & 59.27 & 137 & 68.16 & 137 & 68.16 \\
\hline Women & 101 & 40.73 & 248 & 100 & 64 & 31.84 & 201 & 100 \\
\hline
\end{tabular}

Table 2. Means and Standard Deviation of the Three OWEI Subscales in 2004 and 2018.

\begin{tabular}{|c|c|c|c|c|c|c|c|c|}
\hline \multirow{3}{*}{ Variable } & \multicolumn{4}{|l|}{2018} & \multicolumn{4}{|l|}{2004} \\
\hline & \multicolumn{2}{|c|}{$\operatorname{Men}(\mathrm{N}=147)$} & \multicolumn{2}{|c|}{ Women $(\mathrm{N}=101)$} & \multicolumn{2}{|c|}{$\operatorname{Men}(\mathrm{N}=137)$} & \multicolumn{2}{|c|}{ Women $(N=64)$} \\
\hline & M & SD & $\mathbf{M}$ & SD & M & SD & $\mathbf{M}$ & SD \\
\hline Interpersonal skills & 5.5914 & 0.7564 & 5.4238 & 0.8681 & 5.7586 & 0.5642 & 5.7427 & 0.4907 \\
\hline Initiative & 5.2202 & 0.8100 & 5.2048 & 0.8537 & 5.4033 & 0.5748 & 5.6416 & 0.5547 \\
\hline Dependable & 5.5034 & 0.8984 & 5.3819 & 0.8579 & 5.8217 & 0.5661 & 5.9509 & 0.5478 \\
\hline
\end{tabular}

In order to investigate that the mean differences are statistically significant, ANOVA (analysis of variance) was performed and the results are shown in table 3.The results of univariate analysis of variance for all three Occupational Work Ethic Inventory (OWEI) subscales in 2018 indicated that the respondents grouped by gender on interpersonal skills, initiative and dependable subscales did not meet the established level (.05) for significant results used in this study (see Table 3). The F-values computed for each of the items are as follows (a) interpersonal skills with $\mathrm{F}=2.61$ * and Pr. $=.1072$, (b) initiative $\mathrm{F}=0.02 *$ and $\mathrm{Pr}$. $=.8851$, and (c) dependable, with $\mathrm{F}=1.15^{*}$ and $\mathrm{Pr}$. $=.2856$. While the results of OWEI subscales in 2004 indicated that the respondents grouped by gender on initiative subscales did 
meet the established level (.05) for significant results used in this study.

Table 3. Univariate One-Way ANOVA Analysis of Variance for the Three OWEI Subscales for the Factor of Sex in 2018 and 2004.

\begin{tabular}{lllllllll}
\hline Variable & $\mathbf{2 0 1 8}$ & & & $\mathbf{2 0 0 4}$ & & \\
\cline { 2 - 8 } & df & SS & F & Pr. & df & SS & F & Pr. \\
\hline Interpersonal skills & 1 & 1.6820662 & $2.61^{*}$ & .1072 & 1 & 0.01106850 & $0.04^{*}$ & .8463 \\
Initiative & 1 & 0.0142190 & $0.02^{*}$ & .8851 & 1 & 2.47750268 & $7.66^{*}$ & .0062 \\
Dependable & 1 & 0.8838584 & $1.15^{*}$ & .2856 & 1 & 0.72820507 & $2.32^{*}$ & .1294 \\
\hline
\end{tabular}

$* \mathrm{p}<.0 .05$.

The findings indicated that significant differences were detected for initiative between women and men in the 2004 data set, but not in the 2018 data set. No significant differences were detected between women and men for interpersonal skills or dependability in either set of data.

\section{Discussion}

The work ethic has obviously changed over the time in our study. Judging from the means of our grouped scales for each year, the scores of both the men and women for interpersonal skill, initiative and dependable in 2018 was lower than those in 2004 data set. The evidence of the change suggested that the decline of work ethical behavior in workplace happed not only on women, but also on men.

The reason for the decline of work ethic lies in the changed ideas of today's people which caused by the rapid economic development. Today's employee would like to bear their responsibility based on the principle of equivalent exchange and making money for an individual benefits rather than devotion and sacrifice for their work unit. In the view of today's employees, devotion and sacrifice will benefit others at the expense of themselves. If collective honor has to be obtained through their sacrifice, then they will carefully consider the situation to make sure what's sacrifice can be somehow made up for. Some researcher labeled the phenomenon as "emphasis on material values" or "egoistic materialism. The new trend indicated that people take more and more personal interests and their individual needs into consideration and make them priorities. Thus, the worship of money have become very prevalent and money orientated behavior are obviously among workers in workshops. This also shows that the "danwei" (work unit) do not play any longer a critical role in personal decision-making or in social regulation-choosing.

The data in 2004 showed that there was only a significant difference on initiative between the women and men. But in the 2018 data set, there was no such significant difference exists among the participants. One possible explanation for the initiative change is that Chinese tradition culture and contemporary economic policy has a great influence on employees in the workplace.

In 2004, many women are bearers for house work according to Chinese traditional division of men and women. Traditional society request women stay at home to be a good wife and loving mother. If a woman came out from their family to work, she was very cherish the opportunity and behaved very initiative in workplace. Meanwhile, women have to accept the challenge from men. They always confronted with the issues such as conflicting responsibilities at home and at work, the obsolescence of skills, glass ceiling phenomenon on promotion, readjustment problems and sex discrimination. Therefore, women workers must work harder than men to prove they can do the job as well as men can. Furthermore, most of the women workers have been trained with the beliefs and values of Confucianism, Taoism, Buddhism, and folk religions which required them to take their responsibility by their parents and leaders. Under such guidance, female workers were willing to follow regulations, obey the leadership, show up punctually, do work carefully, be more honest, reliable and dependable to content their conscience and manifest the loyalty to their employers. Finally, the negative influence of the opening policy (decided in 1978) had less functional impact on women workers' ethical value at that time and job opportunity for women is not as much as today. All of these factors kept women work more initiative than men in 2004. However, the working environment for women has been changed a lot in today's society.

It is a new period now. The traditional gender division mode of "Men outside, women inside" cannot keep up the pace of modern society and the gender bias is gradually eliminated for the purpose of achieving harmonious development of society. Therefore, women's social status have been improved a lot.

Chinese government have issued and revised a series of laws and regulations to protect women's right such as " The Constitution of the People's Republic of China"; "Labor Law of the People's Republic of China"; "Labor Contract Law of the People's Republic of China"; "Employment Promotion Law of the People's Republic of China"; "PRC Marriage Law"; "Law of the People's Republic of China on the Protection of Women's Rights and Interests" and "Female Employee Protection Ordinance". Although some of these laws and regulations had stipulated to protect the right for women workers for a very long time, but awareness of the society for executing these laws and regulations in the past is not as strong as today. These policies enhanced women's confidence to take part in the social work and make women act not only a single role, but also an important role in the society. Now, more and more "Strong women" occurred in every line of the industry and they exhibited they can do the job good as well as men can. They also show that they have the competency which men have. The "strong women" also helped the other women to win their social status and earned a good fame for women to share the domination of the world. 
The rapid development of vocational education in China also helped women workers to get more chances to receive better training and education to help them to improve their knowledge and skills so that they can easily get the job in a new, broad, free and open society than before. As we all know, there is a worldwide financial crisis in 2007-2008. China had already experienced a economic downturn, and the lack in demand from abroad meant factory closures, resulting in high job losses all over China. In order to solve the employment issues, government had pinned great attention on vocational education and they took vocational education as an employment education. They designed the market-oriented lessons to train women worker adapting the modern society. Chinese government also take measures to help women workers sign job contract with companies, such as enrolling order training students, free training of unemployment women workers (JIN Fenghua, 2011) [34]. All these measures reduced the worries of women's unemployment. Furthermore, many irresponsible workers have lost their job during the unemployment movement in the international financial crisis. Lianyi factory is not an exception. They fired some workers who is lack of the sense of good work ethic. The participants in our study just the remain workers with strong work ethic. These workers had cultivated a good work ethic habits and behaved themselves very good. Therefore, there is no gender difference on initiative in our study.

Above mentioned reasoning, however, does not account for the fact that all women workers have the same initiative as men. It only reflects there is no any significant difference for initiative between men and women in our study. To understand the whole gender difference on work ethic in China, we need to do a further research with a large scaled survey. We also need to examine the changing trend for work ethic among the new generation workers, for right now, the only one child generation (the child was born under the policy of Chinese Family Plan) had fluxed into the work market. They grow up accompanied by the policy of the reform and open-up. They experienced the change of social structure in China and received a quite different education with the older generation. All these changes made them formed a different belief and value on their life attitude and work attitude.

\section{Conclusions}

The study was designed to revisit research done 14 years ago by Hill (2004) and was needed to show how work ethic attributes might have changed during that period of time. The findings in this study present to us not only on the work ethic differences among the women and men, but also potential reasons for women workers' changed perception of work ethic, impacts of work ethic on their work performance and the work characters for today's workers. Some of the findings of this study matched well with the results of earlier studies and reinforced the work ethic differences among women and men workers.

Based on the analysis of 2018 collected data, we found all the subscales in the Occupational Work Ethic Inventory (OWEI) had showed no significant difference between women and men. However, there was a significant difference on initiative in 2004 collected data. This suggested that the attitude toward initiative between women and men will change over the time. Future research could attempt to figure out the changing trend for initiative and the change as well as interpersonal skills and dependability of the women and men. The present study raises issues concerning the meaning of such a gender difference on work ethic, but it provides only tentative examination results to the gender difference among the three main characters of work ethic. Although considerably more work is required to understand the dynamics of the development of such gender disparities on interpersonal skills, initiative and dependability, the changing trend and changing model would worth a further observation.

This study suggests that managers, union leaders and public policymakers will face new challenges on how to guide workers to form a good work ethic and apply it into their work in the years to come. Workers should learn how to avoid the bad influence on work ethic in the rapid changing world and try to be a positive worker in the future.

\section{Acknowledgements}

This project was sponsored by China Scholarship Council \&Humanities and Social Sciences Planning Fund Project of the Ministry of Education of the People's Republic of China (\#18YJA880002).

\section{References}

[1] Bengt. Furaker, Kristaina, Hakansson and Jan Ch. Karlssson (2012). Routledge Studies in Management, Organizations and Society: Commitment to Work and Job Satisfaction Studies of Work Orientations. Routledge, 2012.

[2] Jesook Song (2011). New Millennium South Korea Neoliberal Capitalism and Transnational Movements. Milton Park, Abingdon, Oxon, [England]; New York: Routledge, 2010.

[3] Jill Casner-Lotto, Linda Barrington (2006). Are They Really Ready To Work? Employers' Perspectives on the Basic Knowledge and Applied Skills of New Entrants to the 21st Century U. S. Workforce. The Conference Board Inc. The partner for 21st Century Skills, Corporate Voices for Working Families, and the Society for Human Resource Management in USA, 2006.

[4] Max Weber. The Protestant Ethic and the Spirit of Capitalism. Economic sociology, 1905.

[5] Xu S, W ang Q. Content and construct of counterproductive work behavior in a Chinese context Social behavior and personality. an international journal, 2013, 41 (6): 921-932.

[6] Cynthia Le Rouge, Anthony Nelson, J. Ellis Blanton. The impact of role stress fit and self-esteem on the job attitudes of IT professionals. Information \& Management 43 (2006) 928938. 
[7] M. R. Merrens, J. B. Garrett (1975). The Protestant ethic scale as a predictor of repetitive work performance. Journal of Applied Psychology, 1975 (60), 125-127.

[8] J. Greenberg (1977). The protestant work ethic and reactions to negative performance evaluations on a laboratory task. Journal of Applied Psychology, 1977 (62), 682-690.

[9] M. R. Blood (1969). Work values and job satisfaction. Journal of Applied Psychology, 1969 (53), 456-459.

[10] Marion Hersh (2017). Professional Ethics and Social Responsibility: Military Work and Peace building. IFAC Papers On Line 50-1 (2017) 10592-10602.

[11] Berry, L. R., \& Glenn, R. E. (2004). The ABC's of a good work ethic. Education Digest, 69 (8), 4.

[12] Yahya Safari, Nasrin Yoosefpour. Dataset for assessing the professional ethics of teaching by medical teachers from the perspective of students in Kermanshah University of Medical Sciences, Iran (2017), Data in Brief 20 (2018) 1955-1959.

[13] Gitmore, J. (2007). One thing hasn't changed-hard work pays off. Des Moines Business Record, 25 (46), 33.

[14] Hamid Ebadollahi Chanzanagh, Mahdi Akbarnejad. Do women have lower work ethic in an Islamic society? A casestudy in Iran. 2011 2nd International Conference on Humanities, Historical and Social Sciences, IACSIT Press, Singapore, 2011 (17), 133-137.

[15] John P. Meriac a, Taylor L. Poling, David J. Woehr. Are there gender differences in work ethic? An examination of the measurement equivalence of the multidimensional work ethic profile. The Official Journal of the International Society for the Study of Individual Differences, 2009 (47), 209-213.

[16] D'Arcy A. Becker \& Ingrid Ulstad (2007). Gender Differences in Student Ethics: Are Females Really More Ethical? Plagiary: Cross-Disciplinary Studies in Plagiarism, Fabrication, and Falsification, 77-91.

[17] Elizue, D. (1994). Gender and work values: A comparative analysis. Journal of Social Psychology, 134 (2), 201-212.

[18] Petty, G. C., \& Hill, R. B. (1994). Are women and men different? A study of the occupational work ethic. Journal of Vocational Education Research, 19 (1), 71-89.

[19] F. Stanford Wayne (1989). An instrument to measure adherence to the Protestant Ethic and contemporary work values. Journal of Business Ethic, 793-804.

[20] Furnham, A. \& Muhiudeen, C. (1984). The protestant work ethic in Britain and Malaysia. Journal of social Psychology, $122,157-161$

[21] Miller, D. (1981). Differences in the protestant work ethic values of selected freshman and senior students at a land grant university. Unpublished doctoral dissertation Oregon State University.
[22] David J. Cherrington. (1980). The work ethic: Working values and values that work. New York. Amacon. Cherrrington, D. J. 1980,45

[23] Hill, R. B., \& Petty, G. C. (1995). A new look at selected employability skills: A factor analysis of the occupational work ethic. Journal of Vocational Education Research, 20 (4), 59-73.

[24] Eisenberger, R. (1989). Blue Monday: the loss of the work ethic in America. New York: Paragon House.

[25] Michael J. Miller, David J. Woehr \& Natasha Hudspeth (2002). MONOGRAPH: The Meaning and Measurement of Work Ethic: Construction and Initial Validation of a Multidimensional Inventory. Journal of Vocational Behavior 2002 (60), 451-489.

[26] John T. Parkhurst, Matthew S. Fleisher, Christopher H. Skinner, David J. Woehr, Meredith L. Hawthorn-Embree. Assignment choice, effort, and assignment completion: Does work ethic predict those who choose higher-effort assignments? Learning and Individual Differences 2011 (21), 575-579.

[27] Liu Jing (2011). A Research on the Women Workers Discrimination Phenomenon. Journal of Legal System and Society, 2011 (15), 188.

[28] D. Arcy A. Becker \& Ingrid Ulstad (2007). Gender Differences in Student Ethics: Are Females Really More Ethical? Plagiary: Cross-Disciplinary Studies in Plagiarism, Fabrication, and Falsification, 77-91.

[29] Mary Stergiou-Kita, Marc Lafrance, Cheryl Pritlove. Examining theoretical approaches to men and masculinity in the context of high-risk work: Applications, benefits and challenges (2017), Safety Science Safety Science 96 (2017) 150-160.

[30] Steve Minter. (2012). U. S., China Headed on Different Manufacturing Trade Paths. manufacturing export gap between U.S. and China continues to grow, MAPI reports, Mar. 5, 2012.

[31] LV Hong-fen, YU Cen (2012), Research on Competitiveness and Complementarity of Bilateral Trade between China and Brazil, Journal of International Trade, 2012, 56-64

[32] Hill R. B. (1996). Work ethic differences in vocational education students and full-time employed workers. Journal of Vocational Education Research, 21 (3), 13-29.

[33] Petty, G. C., \& Hill, R. B. (2005). Work ethic characteristics: Perceived work ethics of supervisors and workers. Journal of Industrial Teacher Education, 42 (2), 1-16.

[34] JIN Fenghua (2011). A Study on Gender Differences of Job Satisfaction of College Managers. Journal of China Women's University, 2011 (1), 31-36. 